\title{
Penerapan Alat Pengasapan Ikan Tipe Kabinet Untuk Meningkatkan Produksi Ikan Asap Di Industri Rumah Tangga Kecamatan Weda Halmahera Tengah
}

\author{
Bambang Tjiroso*, Said Hi Abbas \\ Fakultas Teknik, Universitas Khairun \\ email: bambangtjiroso@unkhair.ac.id
}

\begin{abstract}
Smoked fish is a fish processing product that is very popular with consumers in Indonesia. Smoked fish production in Indonesia, especially in Weda District, Central Halmahera District, still has various problems in the production process because the tools used in daily smoked fish production are still conventional. PKM activity partner is one of the smoked fish home industries located in Weda District, Central Halmahera. Conventional smoking tools are only made of wood and racks made of bamboo and are still open so that the efficiency of smoke for smoking fish is less than optimal. Therefore, through PKM Kubermas, it will be carried out to replace conventional fish smoking equipment owned by partners with cabinet-type smoking equipment to increase production yields. The service implementation process is divided into 7 stages, namely the preparation stage, socialization, making tools, socializing the use of tools, mentoring and evaluation. The results achieved are the dimensions of the smoked fish equipment made with dimensions of length $120 \mathrm{~cm}$, width $80 \mathrm{~cm}$ and height $200 \mathrm{~cm}$, while the time required for smoked fish production is more efficient, namely 2 to 3 hours in one production. It uses less fuel at one time because the smoker is closed.
\end{abstract}

Keywords: cabinet type smoking device, smoked fish, PKM Kubermas, Central Halmahera

\begin{abstract}
Abstrak
Ikan asap merupakan produk pengolahan ikan yang sangat disukai oleh konsumen di Indonesia. Produksi ikan asap di Indonesia khususnya di Kecamatan Weda, Kabupaten Halmahera Tengah masih memiliki berbagai permasalahan dalam proses produksinya karena alat yang digunakan dalam produksi ikan asap sehari-hari masih bersifat konvensional. Mitra kegiatan PKM adalah salah satu industri rumah tangga ikan asap yang berada di Kecamatan Weda, Halmahera Tengah. Alat pengasapan konvensional hanya terbuat dari kayu serta rak yang terbuat dari bambu dan masih bersifat terbuka sehingga efisiensi asap untuk mengasap ikan kurang opimal. Oleh karena itu, melalui PKM Kubermas akan dilakukan mengganti alat pengasapan ikan konvensional yang dimiliki mitra dengan alat pengasapan ikan tipe kabinet untuk meningkatkan hasil produksi. Proses pelaksanaaan pengabdian dibagi menjadi 7 tahapan, yaitu tahap persiapan, sosialisasi, pembuatan alat, sosialisasi penggunaan alat, pendampingan dan evaluasi. Hasil yang dicapai adalah dimensi alat pengasapan ikan yang dibuat berdimensi panjang $120 \mathrm{~cm}$, lebar $80 \mathrm{~cm}$ dan tinggi $200 \mathrm{~cm}$, sedangkan waktu yang dibutuhkan untuk produksi ikan asap lebih efisien yaitu 2 sampai 3 jam dalam sekali produksi. Pengunaan bahan bakar pada sekali produksi lebih sedikit karena alat pengasapan ini bersifat tertutup.
\end{abstract}

Kata Kunci: alat pengasapan tipe kabinet, ikan asap, PKM Kubermas, Halmahera Tengah

\section{PENDAHULUAN}

Letak geografis indonesia yang dikelilingi perairan membuat indonesia memiliki sumber daya perikanan dan kelautan yang berpotensi besar untuk dijadikan landasan pembangunan ekonomi berbasis sumber daya alam, namun pemanfaatan dan pengelolahan sumber daya alamnya belum opimal. Hal ini karena sebagian sistem pengolahan masih menggunakan cara tradisional. Salah satu metode tradisional pengolahan ikan yang 
sering digunakan oleh kebanyakan masyarakat adalah pengolahan ikan dengan cara pengasapan. Pengasapan ikan merupakan sala satu cara pengolahan atau pengawetan produk hasil perikanan dengan teknik melekatkan dan memasukan berbagai senyawa kimia asap ke dalam bahan pangan [1]

Ikan asap merupakan produk pengolahan ikan yang sangat disukai oleh konsumen baik di Indonesia maupun di mancanegara karena rasanya yang khas dan aromanya yang spesifik. Namun demikian, produksi ikan asap di Indonesia khususnya di Kecamatan Weda, Kabupaten Halmahera Tengah masih memiliki berbagai permasalahan dalam proses produksinya karena alat yang digunakan dalam produksi ikan asap sehari-hari masih bersifat konvensional. Alat pengasapan konvensional banyak memiiki kelemahan yang tentunya membuat proses produksi ikan asap sering terhambat. Sehingga jumlah produksi dan permintaan pasar terhadap ikan asap menjadi tidak seimbang.

Mitra kegiatan PKM ini adalah salah satu industri rumah tangga ikan asap yang berada di Kecamatan Weda, Halmahera Tengah. Industri rumah tangga ikan asap ini masih beroperasi menggunakan alat pengasapan konvensional. Alat pengasapan konvensional hanya terbuat dari kayu serta rak yang terbuat dari bambu dan masih bersifat terbuka sehingga efisiensi asap untuk mengasap/mematangkan ikan kurang opimal. Permasalahan utama yang menghambat proses produksi ikan asap di industri rumah tangga ikan asap di Kecamatan Weda adalah penggunaan alat pengasapan ikan masih bersifat konvensional.

Tujuan dari kegiatan PKM ini adalah menggati alat pengasapan ikan konvensional dengan alat pengasapan ikan yang moderen dengan sistem terutup. Pengasapan dengan sistem tertutup lebih menguntungkan dan kualitas ikan asap yang dihasilkan lebih tinggi [2]

\section{METODE PENGABDIAN}

Pelaksanaan kegiatan pengabdian ini terbagi dalam berbagai tahapan yang akan di uraikan sebagai berikut:

1. Tahapan Persiapan, pada tahapan ini ini tim PKM akan melakukan serangkaian persiapan sebelum program PKM dimulai diakukan. Persiapannya yaitu breafing dan persiapan alat dan bahan yang akan digunakan untuk pembuatan alat pengasapan ikan serta kegiatan sosialisasi.

2. Tahapan sosialisasi, sosialisasi ke mitra perlu diakukan untuk memberikan informasi dan gambaran terkait pelaksanaan kegiatan PKM

3. Proses pembuatan alat pengasapan ikan tipe kabinet dilaksanakan di Laboratorium Proses Produksi Fakultas Teknik Universitas Khairun oleh tim PKM.

4. Tahapan sosialisasi yang dilakukan oleh tim adalah pemaparan tentang komponen-komponen alat pengasapan ikan sekaigus pelatihan cara pengoperasian alat pengasapan yang akan digunakan oleh mitra. Proses sosialisasi ini melibatkan seluruh anggota mitra sehingga bisa menambah wawasan dan pengalaman mitra terhadap proses dan alat pengasapan ikan. lokasi sosialisasi direncanakan dilakukan di lokasi proses produksi ikan asap milik mitra.

5. Tim PKM akan melakukan pendampingan proses produksi ikan asap oleh mitra. Hal ini dilakukan untuk mengatasi kendala mitra dalam penggunaan alat pengasapan ikan sekaligus mengawasi proses produksi ikan asap yang dilakukan oleh mitra. Selama kegiatan pendampingan akan dilakukan pencatatan untuk kepentingan pelaporan, evaluasi dan publikasi. 


\section{HASIL DAN PEMBAHASAN}

A. Pelaksanaan Sosialisasi ke Mitra Pelaksanaan kegiatan PKM Kubermas tahun 2020 di awali dengan melakukan sosialisasi kepada mitra terkait kegiatan yang akan dilakukan dilokasi mitra. Sosialisasi yang dilakukan yaitu menunjukan ke mitra desain alat pengasapan ikan tipe kabinet yang akan dibuat dan inovasi teknologi dari alat yang akan digunakan oleh mitra.

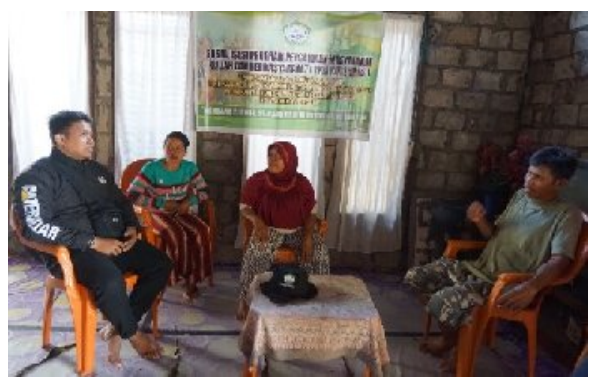

Gambar 1. Pelaksanaan sosialisasi ke mitra

\section{B. Pembuatan Alat Pengasapan Ikan}

1. Pembuatan Rangka

Rangka yang dibuat menggunakan besi siku dengan ukuran $4 \times 4 \mathrm{~cm}$ dengan ketebalan $2 \mathrm{~mm}$ dengan dimensi alat yaitu panjang $120 \mathrm{~cm}$, lebar $80 \mathrm{~cm}$ dan tinggi $200 \mathrm{~cm}$. Penyambungan besi dilakukan dengan menggunakan las listrik.

2. Pembuatan Ruang Pembakaran

Ruangan pembakaran ini berfungsi untuk menampung bahan bakar yang dipakai untuk proses pengasapan ikan. Ruang bakar ini berbentuk persegi panjang dan terbuat dari besi plat dengan ketebalan $2 \mathrm{~cm}$.

3. Pembuatan Rak Pengasapan Ikan

Rak pengasapan pada alat pengasapan tipe kabinet ini berjumlah 5 buah rak susun. Rak ini berfungsi untuk menaruh atau meletakan ikan yang akan diasapi. Jarak antara rak adalah $25 \mathrm{~cm}$. jarak ini sangat dimungkinkan asap yang keluar dari ruang pembakaran bisa tersikulasi ke bagianbagian rak alat pengasapan yang lain.
4. Pembuatan Penutup Ruang Pembakaran

Penutup dari ruang pembakaran berfungsi untuk mendistribusikan asap dari ruang pembakaran ke ruang pengasapan. Penutup terbuat dari besi plat dengan ketebalan $1,6 \mathrm{~cm}$ dan diameter lubang $19 \mathrm{~mm}$.

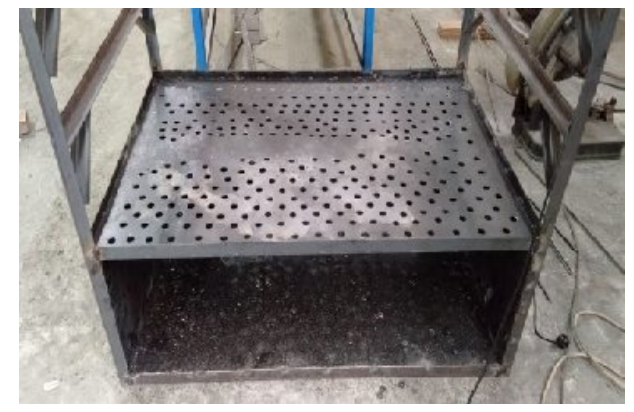

Gambar 2. Penutup ruang pembakaran

\section{Pemasangan Plat Aluminium}

Keseluruan bagian dari alat pengasapan tipe kabinet terbuat dari plat aluminium. Plat aluminium yang digunakan disambungkan menggunakan paku ripet. Ketebalan plat ada $1 \mathrm{~mm}$.

C. Sosialisasi penggunaan alat pengasapan ikan dan pendampingan proses produksi ikan asap

Tahapan selanjutnya yang dilakukan oleh tim PKM Kubermas yaitu mensosialisasikan komponen-komponen dari alat pengasapan ikan serta menjelaskan kepada mitra cara penggunaan dari alat pengasapan ikan tipe kabinet. Sosialisasi tim PKM bertujuan untuk menambah wawasan dan pengetahuan kepada mitra terkait penggunaan alat pengasapan ikan tipe kabinet.
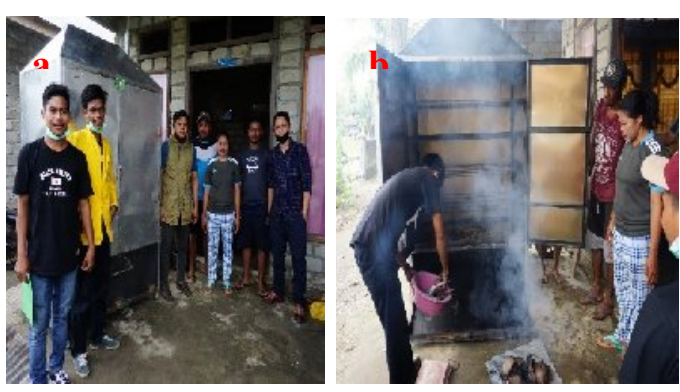

doi: https://doi.org/10.37859/jpumri.v4i2.2210 
Gambar 3. Sosialisasi penggunaan alat dan pendampingan proses produksi ikan asap

Tim PKM Kubermas juga melakukan pendampingan produksi ikan asap dengan menggunakan alat pengasapan tipe kabinet. Pendampingan proses produksi dilakukan selama kegiatan Kubermas dilaksanakan yaitu 2 bulan. Pendampingan bertujuan untuk mengatasi kendala mitra dalam penggunaan alat pengasapan ikan sekaligus mengawasi proses produksi ikan asap.

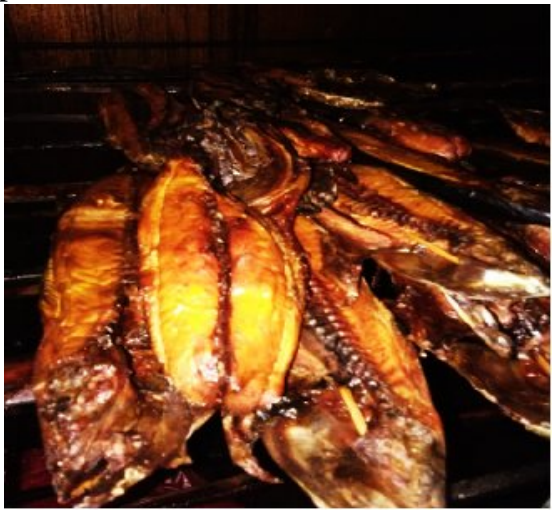

Gambar 4. Ikan asap hasil produksi

Hasil pembuatan alat pengasapan ikan tipe kabinet yang digunakan untuk produksi ikan asap diketahui memiliki beberapa keunggulan yaitu jumlah pemakaian bahan bakar untuk proses pengasapan ikan lebih hemat dibandingkan menggunakan cara tradisional yang biasa digunakan oleh mitra. Hal ini karena alat pengasapan tipe kabinet sudah menggunakan sistem tertutup, dimana asap yang dihasilkan dari proses pembakaran tidak terbuang langsung ke lingkungan sekitar. Sedangkan waktu yang dibutuhkan untuk proses pengasapan ikan juga lebih cepat dibandingkan dengan cara tradisional. Waktu pengasapan untuk satu kali produksi 2 sampai 3 jam. Waktu pengasapan ikan menggunakan lemari pengasapan ikan, dibutuhkan waktu 2-3 jam hingga ikan matang sempurna. Dibandingkan dengan sebelum menggunakan lemari pengasapan yaitu dengan cara sistem terbuka sehingga asap mudah terbawa oleh angin. Hal ini yang menyebabkan waktu pengasapan lebih lama sekitar 4-8 jam dalam sekali produksi [3]

\section{SIMPULAN}

Berdasarkan hasil kegiatan PKM dapat disimpulkan beberapa hal sebagai berikut:

1. Waktu yang dibutuhkan mitra untuk produksi ikan asap lebih efisien yaitu 2 sampai 3 jam dalam sekali produksi

2. Pengunaan bahan bakar pada sekali produksi lebih sedikit.

3. Meningkatnya pemahaman dan kemampuan mitra dalam pengoperasian alat pengasapan moderen

4. Memberikan pembelajaran dan pengalaman kepada mahasiswa Kubermas tahap I tentang proses pengabdian kepada masyarakat.

\section{UCAPAN TERIMAKASIH}

Tim PKM Kubermas mengucapkan terima kasih kepada LPPM UNKHAIR yang telah memberikan dana kegiatan melalui Program Kemitraan Masyarakat (PKM) KUBERMAS tahun 2020. Tim juga mengucapkan terima kasih kepada mitra dan semua pihak yang membantu terselenggaraanya kegiatan ini.

\section{DAFTAR PUSTAKA}

[1] B. S. B. Utomo, S. Wibowo, and T. N. Widianto, Asap cair: cara membuat dan aplikasinya pada pengolahan ikan asap. Penebar Swadaya Grup., 2012.

[2] Maripul Y, "Mesin Pengasapan Ikan Sederhana,". Bul. Tek. Pertan. 9, 2004.

[3] B. Tjiroso, R. M. Nur, and A. W. Bustan, "Penggunaan lemari pengasapan ikan untuk meningkatkan produksi pada industri rumah tangga di Kabupaten Pulau Morotai," vol. 22, no. 1, pp. 51-54, 2020. 